\title{
Development of Documentary Film Media Based on Historical Sites in Maritime History
}

\author{
Ida Liana Tanjung ${ }^{1}$, Hidayat $^{2}$, Ika Purnama Sari ${ }^{3}$ \\ \{Idatanjung78@gmail.com¹, hidayat@unimed.ac.id²,ikapurnamasari007@gmail.com ${ }^{3\}}$ \\ Department of History, Faculty of Social Sciences, Universitas Negeri Medan, Indonesia
}

\begin{abstract}
This study examines the development of historical site-based documentary film media in maritime history courses. This research aims to find out the function of historical site-based documentary film media in learning maritime history, describing maritime historical sites in North Sumatra, producing documentary products on North Sumatra maritime historical sites, and testing the feasibility of documentary films to improve student competency in history courses maritime. The method used in this research is the Research and Development (R\&D) method. Validation data analysis conducted by material experts and media experts on documentary films of maritime historical sites in North Sumatra were respectively obtained grades 3, 62 and 3, 87. The documentary film eligibility test was also carried out by 100 students of the Department of Education History of FIS Unimed which takes a maritime history course with a value of 3.45 or valid. Thus it was concluded that the documentary media of maritime historical sites in North Sumatra was suitable to be used as a medium for learning maritime history.
\end{abstract}

Keywords: Documentary Film, Historical Sites, Maritime.

\section{Introduction}

Maritime history is a new study in the study of history in North Sumatra and also a new course in the History of the Faculty of Social Sciences, Unimed. This subject only began to be taught in 2017. Based on curriculum studies conducted by the Group of Historical Expert Lecturers, maritime history needs to be included in the History Education KKNI Curriculum. This is because North Sumatra is an important area in Indonesia's maritime studies. Parts of North Sumatra are located on the east and west coasts of Sumatra. These two regions have strategic positions in the trade routes in the archipelago from the pre-colonial era to independence. Maritime activities in North Sumatra have been ongoing since the 6th century $\mathrm{AD}$, namely when Barus became the center of Barus limestone trade in Asia [1].

The disappearance of the narrative of North Sumatra as a maritime area began with the arrival of Western colonialism in the 18th century. The maritime world of Sumatra, which was initially controlled by local rulers, was taken over by the Dutch and British. It is not only maritime political power that is destroyed but also the joints of people's lives. The dominance and hegemony and monopoly of the Dutch colonial power over the maritime sector have caused the decline of the role of the Nusantara community in the field of maritime affairs. Besides, colonial exploitation in the plantation sector had caused a large portion of the local 
workforce to be absorbed into the plantation sector, which greatly benefited the colonial power. A few decades after independence, school children are still taught that our country is an agrarian country.

The lack of understanding of maritime history encourages the Department of Historical Education to make maritime history as one of the courses in the KKNI Curriculum. Based on the results of the pre-survey conducted by researchers in the course of maritime history, maritime history learning that has taken place in the Department of Historical Education has many shortcomings. First, limited student learning resources, and second, the teaching materials available are still Javanese centric, while the material related to maritime history in North Sumatra is still very limited.

This results in contextual learning and students find it difficult to understand teaching material. Aside from the limited resources to learn maritime history, the lack of students understanding maritime history is that maritime history is still descriptive. Based on the conditions and situations of learning maritime history in the Department of History Education, learning media are needed that can facilitate students learning the maritime history and help lecturers deliver teaching materials to students. One of the learning media that can be used by students in learning maritime history is a documentary film based on historical sites or historical relics. Documentary films can make it easier for students to understand teaching material because it has symbol and image content.

The use of documentary films as learning media has been widely carried out by lecturers but is still limited to films produced by the government and television companies in Indonesia. Therefore the documentary film's theme is more on political histories, such as the documentary document on the proclamation of independence, the general attack on March 1, 1948, and the September 30, 1965 movement. While documentary films related to the theme of maritime history are not yet available. This allows students and lecturers to produce documentaries under the learning needs of maritime history.

One source of historical learning that can be used as a documentary film is maritime historical sites scattered throughout the west and east coast of North Sumatra, such as the Port of Barus, Sibolga, Belawan, and Tanjung Balai. This maritime heritage of North Sumatra has not been well utilized as a source of historical learning. Though the use of historical relics is very important in learning history. Through historical sites, students can find evidence of past events, criticize, interpret and compile them into a historical story [2]. The utilization of historical sites as a source of learning has been carried out by lecturers in the Department of Education History of FIS Unimed but still limited to field studies. The results of this field study have not been well documented and still require more comprehensive studies on historical sites in North Sumatra including maritime historical sites.

In the current digital era, the existence of documentaries based on historical sites will greatly assist students in enhancing competence in learning maritime history. Besides, the use of documentary media based on maritime history sites is one way to increase student interest in learning maritime history. Some of the competencies expected in maritime history include (1) able to understand the scope of maritime history, (2) able to explain shipping and trade patterns in Indonesia, (3) able to analyze the process of the formation of ports and coastal cities in North Sumatra, (4) able to track maritime historical sites in North Sumatra since precolonial to independence; and (5) able to make a documentary about maritime history in North Sumatra. Based on the background of the problems above, the researcher is interested in studying the development of historical site-based documentary film media in the course of maritime history. 
Before examining the development of historical site-based documentary film media in the course of maritime history, the concepts of media and documentary films are first understood. The study of instructional media has been widely carried out by experts. One study that discusses learning media is the work of AzharArsyad (2010) entitled Learning Media. In his work, Arsyad explained that the media are an inseparable part of the teaching and learning process for the achievement of educational goals and learning objectives. According to Arsyad, media in the teaching and learning process tends to be interpreted as graphic, photographic, or electronic tools for capturing, processing, and rearranging visual or verbal information [3].

The term learning media is often interpreted also as a tool or communication media. This is in line with the opinion of Gagne 'and Briggs (Arsyad, 2010:4-5)which states that learning media includes tools that are physically used to convey the contents of the subject matter, which consists of books, tape recorders, tapes, video cameras, video recorders, films, slides, photos, pictures, graphics, television, and computers. In other words, the media is a component of learning resources or physical vehicles that contain instructional material in the student environment that can stimulate students to learn.

Based on Sanjaya's study (Sanjaya, 2012:61-76)about learning media, the media are not only limited to tools but also include the environment and all forms of activities that are conditioned to increase knowledge, change attitudes or instill skills in everyone who uses them. Therefore, to achieve the learning objectives needed appropriate learning media. Based on the type, media can be classified as follows: (1) print media, (2) display media, (3) overhead transparency, (4) audiotape recordings, (5) slide series and filmstrips, (6) multiimage presentation, (7) live video and film, and (8) computers [3]. Media that will be developed in this research are film media or more specifically documentary film media.

Film or live images are images in a frame where frame by frame is projected through the projector lens mechanically so that the screen looks alive. The film moves quickly and alternately to provide continuous visuals. Similar to film, video can depict an object that moves together with natural or suitable sound. The ability of film and video to painting vivid images and sounds gives it its charm. Both types of media are generally used for entertainment, documentation and education purposes. They can present information, explain the process, explain complicated concepts, teach skills or extend time, and influence attitudes.

The use of documentary films in learning will be very useful in completing the basic experiences of students when they are reading, discussing and practicing. The film becomes a representation of an event and can describe a process easily. The film becomes a media that can raise awareness for those who watch it. Theoretically, films provide significant benefits in learning. But it must be recognized that the procurement of documentary films requires a lot of cost and time. While the documentary films available are sometimes not under the needs and learning objectives. Therefore, Hamid (Hamid, 2014:75) argues that in using and producing documentary films, attention must be given to the content, context and purpose aspects contained in the film. In this context, lecturers are demanded their creativity to produce a decent and representative documentary. Lecturer creativity is one of the requirements in developing learning media in tertiary institutions. This is under the principle of teacherprenuers who view educators as people who can write books, blogs, articles and design learning media (Abrar, 2015:6)

The limited documentary films that can be used as learning media are the basis for researchers to develop documentary films under the expected learning objectives. The documentary that will be developed in this research is a documentary based on maritime history sites. The use of documentary film media in the course of maritime history can help 
students to construct memories of maritime history in North Sumatra. Learning by using documentary film media can be categorized as constructivism learning. This is because students are required to build knowledge based on their respective experiences [7]. Thus, through collecting sources of maritime historical sites and then documenting them in documentary films, students have constructed their knowledge of past events.

The study of historical sites is a field of archeology, but along with the development of Indonesian historiography, historians also make it as an object of study. At present historical sites are no longer understood only as historical relics in ancient times. This refers to the opinion of Sjamsuddin (Sjamsuddin, 2012:63) which states that historical sites are historical relics that are evidence of human society's life that can be seen and touched. As a product of the needs of human life in the form of food board clothing, the variety is very much. But the existence of this site was not originally to inform human activities to future generations. The sites that still exist are only accidental, but the remnants left behind can reveal the socioeconomic life and culture of humans in general.

Household appliances, kitchen utensils, ceramic fragments, weapons for the hunting of stone, copper, bronze or iron, firearms, clothing, porcelain, fortress buildings, castles, tombs, places of worship such as temples, temples, churches, mosques, etc. are part of historical sites. These historical sites are usually over 50 years old and are located in a place or land (Purnamasari, 2011:203). Historical sites can tell a great deal about social, economic, religious and cultural life and human civilization. Usually, these relics of a certain size are collected and displayed in museums that can be visited. From this display, one can learn something about the cultural life of a particular society or nation. Related to maritime history, the relics that can be categorized as maritime historical sites are relics from maritime activities in North Sumatra. This activity covers all aspects of exceeding human activities related to marines such as shipping, trade, fisheries, navigation technology, shipping, culture and coastal and port communities (Hamid, 2018:2; Sulistiyono, 2004:10).

\section{Result and discussion}

In the early stages of the development of historical site-based documentary films in the course of maritime history, a preliminary study was carried out in the form of surveys, literature and field studies. Based on preliminary studies, it is obtained data that learning media in maritime history is still limited. Therefore, efforts are needed to develop learning media that are suitable for the needs of students and the demands of the technological era. One effort that can be made is the development of historical site-based documentary film media. This media can be developed because North Sumatra has maritime historical sites spread across the west and east coast of Sumatra. But for the initial stage of making documentary films only include maritime historical sites on the east coast of Sumatra, namely Kota Cina and Belawan.

In the last few years, documentary films have become a trend film among students, students, and the general public. Documentary film festivals are held both locally and nationally. In the Government Regulation of the Republic of Indonesia Number 23 of 1999 concerning the Implementation of Savings and Management of Record Filming for Story Films or Documentary Films, it is explained that the documentary film recordings or documentary films are basically one of the nation's cultural works as an embodiment of human creativity, taste, and intention and have a role which is very important in upholding 
development in general, especially the development of education, research, development of science and technology and dissemination of information.

Government regulations regarding documentary films are in line with the needs of learning in schools. In the learning process needed media can be used as a tool to spread information. Thus the documentary can be used as information dissemination. Documentary films become interesting media in the current era of technology and information. A documentary film is one of several types of films known in the film world, namely fiction, animation, experimental and documentary films. Among these four types of films, documentaries are considered the most appropriate as a learning medium. This is because the documentary film is a narrative of the facts so there is no engineering in its production [11].

The term documentary film for non-fiction films was proclaimed by John Grierson, according to him documentary film work is an actual creative report [12]. Biran argues that documentaries are films that contain recordings of actual events and actual people, so documentaries do not require interpretation [13]. Documentary films have a distinctive technical character whose main purpose is to get the speed of flexibility, effectiveness, and authenticity of events to be recorded. Generally, documentary films have a simple form and rarely use visual effects. Thus the documentary film can be understood as a film that contains actual or non-fictional events and is presented again with an interesting objective that has a specific purpose. In the cultivation of a documentary, the maker cannot be separated from the calculation and consideration of beauty in constructing conflict in the narrative as an attraction for the audience. However, it should be noted that the truth in documentary films does not always broadcast information purely like textbooks, but it does point to the point of view of several aspects of the human condition. To dramatize the broad and narrow truths, documentaries usually depend on the structure of traditional drama which includes character, exposure, tension, building conflict between power conflicts, confrontation, climax, and problem-solving [15]. According to Ayawaila (2008), four criteria explain that a documentary film is a non-fiction film: (1) every scene in a documentary is a recording of actual events, without imaginative interpretation as in fiction films. If in a fiction film the setting (setting) of the scene is designed in such a way according to the wishes of the time, place in the scene, while in the documentary the background must be spontaneous and authentic with the original situation and condition (as is), (2) what is said in the documentary film based on real events (reality), while in fiction films the contents of the story are based on essays (imaginative).

In documentary films having creative interpretations, then in fiction films they have imaginative interpretations, (3) as a non-fiction film, the director in the production of documentary films observes a real event, then records the image as it is, and (4) if the structure of a story in a fiction film refers to a plot or plot, then in a documentary the concentration is more on the truth of the content and the creativity of the exposure of the content. When making a documentary, the film must have characteristics as a conveyor of information, able to present clear messages to the audience about things that are worth emulating. Besides, as a learning medium, documentary films must be able to shape the character of students and not conflict with customs [11]. Documentary film can become a new perspective and new information in everything that exists, therefore ideas and themes in a documentary are not limited so that anything can be used as a documentary [11].

On this basis, it is possible to make a documentary about the maritime historical sites of North Sumatra. Here are some steps in documentary film making: (1) research. Usually, filmmakers before making documentaries must first collect data on a single theme or conduct in-depth research. As for the sources of data and information in the collection of research data for filmmakers are sources of writing such as books, magazines, newspapers, leaflets. In 
addition to writing sources, filmmakers also use visual sources such as photos, films, videos, paintings, posters, sculptures, and engravings. Location data such as scene and events [11], (2) making a scene. After getting the ripe data, the new filmmaker can make the scenario. Writing documentary screenplays should use the stages of screenplay writing because after all the ability to remember from humans is limited so that this stage can help filmmakers from starting to ensure the formulation of ideas to the full story that is about to be presented to the audience. According to Agustus (2011), the stages that must be passed by a documentary screenwriter there are several stages from starting to make the main idea or premise, the theme of the film, the storyline as the basis of the story, synopsis, outline or treatment that can be chosen one and finally the scenario which is usually rarely made because treatment is considered to be a blueprint for documentary filmmaking.

Furthermore, (3) main ideas and themes. The main idea is the core of the problem that will be raised in the film and the theme is a sentence that explains what the subject will do about the problem. Subjects in the documentary films on maritime history sites are maritime history sites. The theme is documentation of maritime historical sites in North Sumatra in the pre-colonial to colonial period, (4) storyline. Storyline serves to provide a foundation for the story of the film to be made. Technically the writing is usually made short about half a quarto page. In the storyline, there are settings (space and time), problems, storylines, opening, ending, (5) synopsis. A synopsis is a complete description of the storyline of a film, (6) outline. documentary film outlines are similar to feature films, but in films, the stories between scenes have a causal relationship, and (7) documentary screenplay. Serves to provide information on everything that is seen and heard that will later be visualized by the filmmaker.

The language must be to use film language and avoid using winged sentences. For visual columns, the sequence is the scene headings (space and time), scene descriptions (settings, characters and actions, and subjects). The development of documentary films as historical learning media is carried out under procedural research in development. Activities are carried out through theoretical studies including research that is relevant, empirical and under adult learning. Documentary films are validated by experts before being trialed. After the validation results are calculated and show good results, they are then tested in class. After being tested it is analyzed descriptively to produce a conclusion whether the documentary will be developed or not. Table 1 below is the validation data analysis expert documentary film material.

Table 1. The validation data analysis expert documentary film material.

\begin{tabular}{|c|c|c|c|c|c|c|}
\hline \multirow[t]{2}{*}{ no } & \multirow[t]{2}{*}{ criteria } & \multicolumn{4}{|c|}{ rating } & \multirow[t]{2}{*}{ score } \\
\hline & & 1 & 2 & 3 & 4 & \\
\hline 1 & The material shown is variation & & & 3 & & 3 \\
\hline 2 & The presented material is based on facts & & & & 4 & 4 \\
\hline 3 & The presented material suits with the competency & & & 3 & & 3 \\
\hline 4 & $\begin{array}{l}\text { The presented material is under the Semester } \\
\text { Learning Plan }\end{array}$ & & & & 4 & 4 \\
\hline 5 & $\begin{array}{l}\text { Technical presentation of the material under the latest } \\
\text { technology so that it can be repeated }\end{array}$ & & & & 4 & 4 \\
\hline 6 & $\begin{array}{l}\text { The material is presented with clear image sharpness } \\
\text { and volume so it is easy to understand }\end{array}$ & & & 3 & & 3 \\
\hline 7 & The presented material can motivate students & & & & 4 & 4 \\
\hline 8 & $\begin{array}{l}\text { The presented material can be used as information for } \\
\text { education and society }\end{array}$ & & & & 4 & 4 \\
\hline & average & & & & & 3,62 \\
\hline
\end{tabular}


The documentary film made in this study was 30 minutes long. The purpose of making this documentary film media made is to be used during the study of maritime history sub material maritime history sites in North Sumatra. This documentary is expected to make it easier for students to get to know maritime historical sites in North Sumatra. Besides, the documentary film media maritime historical sites in Sumatra will introduce students or students to maritime historical sites in North Sumatra.

The validation assessment for documentary film experts included 8 criteria (Table 1). The first criterion assessment is the material displayed varied with the acquisition of value 3 . According to the validator, the material must be presented more creatively so that students do not feel bored seeing the appearance of documentary film material. The validator suggested that the documentary film is more creative, the picture shown in the documentary must be accompanied by a description. Before showing the material in documentary film media, and opening narrative for documentary films is needed. The second criterion is the material presented based on facts. This is under the criteria of the documentary that the film is based on facts or reality. The acquisition of the second criterion scores 4 . The documentary film on maritime historical sites in North Sumatra is produced based on historical research that has been carried out mainly related to maritime historical sites in the Cities of China and Belawan.

The third criterion assessment is related to the material presented under competencies and obtained a score of 3 . This assessment is based on the expected competency of maritime history learning is that students can explain and understand maritime historical sites in North Sumatra that include Barus, Sibolga, Kota Cina and Belawan, but the material in the documentary film only covers two maritime historical sites namely China City and Belawan, while for the two maritime historical sites it has not been featured in the documentary.

The fourth criterion is the material presented following the Semester Learning Plan. Criteria for getting score 4. Semester Learning Plan in the Maritime History course contains maritime historical sites. This is in line with the opinion of Sanjaya(Sanjaya, 2011:224) that the media used by educators must be following learning material. The fifth criterion in the validation test with material experts is the presentation of material according to the latest technology so that it can be repeated. This criterion is rated 4 because based on the validator's assessment, the media are under the latest technology. Documentary filmmaking is a learning medium in the 21 st century that relies on audio-visual technology. Some material in films such as old film footage was taken from YouTube. Documentary films on historical sites can also be arranged for the duration of their screening.

The sixth assessment is the material presented with clear image sharpness and volume so that it is easy to understand get a value of 3 . The validator assesses the volume is still unclear so the material is not understood. The seventh evaluation criteria namely the material presented can motivate students or students. Documentary film media is one of the learning media that can motivate students, therefore the validator gives a value of 4 . The material in documentary films uses historical data that is synchronized with old photographs and films. This encourages students to find out more about maritime historical sites in North Sumatra. The final evaluation criteria namely the material presented can be used as information for education and society. The validator gives a value of 4 because the material in the media is considered to be able to provide information for education and society. This is in line with the main function of learning media proposed by Kemp \& Dayton (1985:28)that is if the media is used for individuals, groups, or a large number of listening groups can motivate interest or action, present information and give instructions. Based on the validation data analysis conducted by material experts on the documentary films of maritime historical sites in North 
Sumatra, the average value was 3, 62 or valid. The rating scale used is 1 to 4 with details $1=$ invalid, $2=$ less valid, $3=$ valid and $4=$ very valid.

Table 2. Data analysis validation of media documentary films

\begin{tabular}{|c|c|c|c|c|c|c|}
\hline no & criteria & \multicolumn{4}{|c|}{ rating } & score \\
\hline & & 1 & 2 & 3 & 4 & \\
\hline 1 & $\begin{array}{l}\text { The flow of the presentation of the documentary is } \\
\text { coherent so that the storyline is easily understood }\end{array}$ & & & & 4 & 4 \\
\hline 2 & The documentary media is displayed interestingly & & & & 4 & 4 \\
\hline 3 & $\begin{array}{l}\text { Documentary film media displays audiovisual } \\
\text { messages and the appearance of motion }\end{array}$ & & & & 4 & 4 \\
\hline 4 & Documentary film media under the title & & & & 4 & 4 \\
\hline 5 & Media documentary films featuring vivid images & & & & 4 & 4 \\
\hline 6 & $\begin{array}{l}\text { Documentary film media makes it easy for educators } \\
\text { to deliver material }\end{array}$ & & & & 4 & 4 \\
\hline 7 & $\begin{array}{l}\text { Documentary film media uses clear and good sound } \\
\text { systems }\end{array}$ & & & 3 & & 3 \\
\hline 8 & $\begin{array}{r}\text { Documentary film media is easily operated } \\
\text { average }\end{array}$ & & & & 4 & $\begin{array}{c}4 \\
3,87\end{array}$ \\
\hline
\end{tabular}

The validation assessment by documentary film media experts consisted of 8 criteria (Table 2). The first criteria assessment is the flow of the presentation of a documentary film coherently so that the storyline is easily understood to get a value of 4 . The presentation of the documentary film is adjusted to the history of maritime historical sites in North Sumatra that uses periodic so that it is coherent and chronological. The second criteria assessment, namely, documentary film media is shown to be interesting with the acquisition of a value of 4 . Documentary film media must be made interesting to encourage students' motivation and interest to learn. This is in line with the opinion of Aqib(Aqib, 2013:52) which states one of the general principles of making media is interesting. This is because one of the benefits of the media is attracting the attention of students. This interest according to Sumiati and Asra(2007:162)will arouse interest in motivation, activity and learning creativity. Besides, interesting media will be able to help students improve understanding and make it easier to interpret information (Sudjana N dan Rivai, 2013:11)

The third criterion assessment is the documentary film media displaying audiovisual messages and the appearance of motion with the acquisition of value 4 . In the documentary film audiovisual messages have been displayed (seen and heard) and there is an appropriate motion display on the documentary film. This is in line with Susilana and Riyana's (2007:19) film is a medium that presents audiovisual and motion messages. Therefore, the film gives an impressive impression to the viewers. The fourth criterion is the documentary film media according to the title gets a value of 4 . The documentary film media in the study is under the title, namely From China City to Belawan Harbor: Maritime Historical Sites in North Sumatra.

The fifth criterion is the documentary film that displays live images and receives a score of 4. One of the live images shown is activity in the ports of China City and Belawan. Besides, this documentary also featured interviews with speakers. But according to the validator, the image display lacks focus. The sixth evaluation criteria namely documentary film media makes it easier for educators to deliver material to get a value of 4 . Documentary film media is categorized as an audiovisual media that makes it easy for students to understand learning material because it involves all of the five senses. 
The seventh criterion is documentary film media that uses a clear and good sound system that scores 3. According to the validator, the sound system must be improved in quality so that it is clearer and better so that the material presented is understood by students. The eighth criterion, namely, documentary film media is easy to operate, gets a score of 4 . Documentary film media is easily operated by educators and students who will use it as a learning medium. This is because documentary film media can be operated in all computer applications and other communication tools such as Android. Based on the validation data analysis conducted by media experts on the documentary films of maritime historical sites in North Sumatra, the average value was 3,87 or valid. The rating scale used is 1 to 4 with details $1=$ invalid, $2=$ less valid, $3=$ valid and $4=$ very valid.

Table 3. Analysis of the feasibility test for documentary films of maritime historical sites in North Sumatra,

\begin{tabular}{clc}
\hline no & \multicolumn{1}{c}{ criteria } & $\begin{array}{c}\text { average } \\
(100 \text { students })\end{array}$ \\
\hline 1 & $\begin{array}{l}\text { Systematic presentation is coherent so that the storyline is easy to } \\
\text { understand }\end{array}$ & 3,56 \\
2 & $\begin{array}{l}\text { Documentary film media makes it easy for students to understand the } \\
\text { material }\end{array}$ & 3,38 \\
3 & The size and color of the letters used can be easily read & 3,3 \\
4 & The images shown are seen and have captions so that they are easy to & 3,31 \\
& understand & 3,3 \\
6 & The documentary media is displayed interestingly & 3,3 \\
7 & Documentary film media is created creatively and presents a reality & 3,31 \\
8 & Documentary film media displays audiovisual messages & 3,81 \\
9 & Media Documentary Films are displayed under the title & 3,78 \\
& & \\
\end{tabular}

A documentary film on maritime historical sites in North Sumatra was also conducted on students of the Department of Historical Education. They are 2019 odd semester students taking 100 maritime history courses. The feasibility test is carried out by screening documentary films and distributing questionnaires. Based on the analysis of the due diligence, the documentary film on maritime historical sites scored 3.45 or valid. Rating scale 1 to 4 with details $1=$ invalid, $2=$ less valid, $3=$ valid and $4=$ very valid

\section{Conclusion}

The development of historical site-based documentary films in the course of maritime history can be used as a model in the development of other historical learning media. Documentary film media becomes a media that collaborates between research results with technological advancements. In making historical site-based documentary films must be based on historical research first. This research was preceded by surveys, literature and field studies. The data obtained from historical research is then published in the form of audiovisual. Through the development of historical site-based documentary film media, it is hoped that it can improve the effectiveness and efficiency of learning, make it easier for educators to 
explain abstract things, make it easier for students to remember learning material, activate students' imagination and creativity, and learning becomes more scientific.

Based on the validation data analysis conducted by material experts and media experts on the documentary films of maritime historical sites in North Sumatra, respectively obtained grades 3,62 and 3, 87. The feasibility test of the documentary film was also carried out by 100 students of the Department of History Education FIS Unimed who took a maritime history course with a value of 3.45 or valid. Thus it was concluded that the documentary media of maritime historical sites in North Sumatra was suitable to be used as a medium for learning maritime history.

\section{References}

[1] O. W. Wolters, Kemaharajaan Maritim Sriwijaya dan Perniagaan Dunia Abad III - Abad VII. Jakarta: Komunitas Bambu, 2011.

[2] I. dan W. Purnamasari, "Pengembangan Model Pembelajaran berbasis Situs Sejarah Lokal di SMA Negeri Kabupaten Temanggung," J. Paramita, vol. 21, no. 2, pp. 202-212, 2011.

[3] A. Arsyad, Media Pembelajaran. Jakarta: PT. Raja Grafindo Persada, 2010.

[4] W. Sanjaya, Media Komunikasi Pembelajaran. Jakarta: Kencana, 2012.

[5] A. R. Hamid, Pembelajaran Sejarah. Yogyakarta: Penerbit Ombak, 2014.

[6] Abrar, "Pembelajaran Sejarah dan Teacherpreneur," J. Pendidik. Sej., vol. 4, no. 2, 2015.

[7] Y. R. Subakti, "Paradigma Pembelajaran Sejarah berbasis Konstruktivisme," J. SPPS, vol. 24, no. 1, 2010.

[8] H. Sjamsuddin, Metodologi Sejarah. Yogyakarta: Penerbit Ombak, 2012.

[9] S. T. Sulistiyono, Pengantar Sejarah Maritim Indonesia. Jakarta: Direktorat Jenderal Pendidikan Tinggi, Departemen Pendidikan Nasional, 2004.

[10] A. R. Hamid, Sejarah Maritim. Yogyakarta: Penerbit Ombak, 2018.

[11] R. Rikarno, "Film Dokumenter Sebagai Sumber Belajar Siswa," J. Ekspresi Seni, vol. 17, no. 1, pp. 129-149, 2015.

[12] G. R. Ayawaila, Dokumenter dari Ide sampai Produksi. Jakarta: FFTV-IKJ, 2008.

[13] M. Y. Biran, Kamus Kecil Istilah Film. Jakarta: B.P. SDM CITRA, 1997.

[14] P. Himawan, Memahami Film. Yogyakarta: Homerian Pustaka, 2008.

[15] M. Rabiger, Directing Documentary, Second Edi. Boston: Focal Pres, 1997.

[16] E. Agustus, "Tahapan Produksi Film Dokumenter," 2011. .

[17] W. Sanjaya, Perencanaan dan Desain Sistem Pembelajaran. Jakarta: Kencana, 2011.

[18] D. . Kemp, J.E. dan Dayton, Planning and Producting Instructional Media (Fifth Editional). New York: Harper \& Row Publisher, 1985.

[19] Z. Aqib, Model-model, Media dan Strategi Pembelajaran Kontekstual (Inovatif). Bandung: Yrama Widya, 2013.

[20] Sumiati dan Asra, Metode Pembelajaran. Bandung: Wacana Prima, 2007.

[21] Sudjana N dan Rivai, Media Pengajaran. Bandung: Sinar Baru Algesindo Offset, 2013.

[22] R. dan R. Susilana, Media Pembelajaran. Bandung: Wacana Prima, 2007. 